\title{
Global trends in testosterone prescribing, 2000-2011: expanding the spectrum of prescription drug misuse
}

\section{David J Handelsman MB BS, FRACP, PhD, Director \\ ANZAC Research Institute Concord Hospital, University of Sydney, Sydney, NSW. \\ djh@anzac.edu.au}

MJA 2013; 199: 548-551 doi: 10.5694/mjal3.1011
S ince the first report of clinical use of testosterone in $1937,{ }^{1} 2$ years after its Nobel Prizewinning identification as the male testicular steroid, ${ }^{2,3}$ the sole unequivocal therapeutic indication for testosterone is in replacement therapy for pathological androgen deficiency (AD). This includes disorders of the testis, where damaged Leydig cells cannot produce sufficient testosterone, and of the hypothalamus and/or pituitary, where impaired pituitary luteinising hormone (LH) secretion reduces testosterone production by Leydig cells. Pharmacological androgen therapy - the use of testosterone (or its synthetic androgen analogues) beyond replacement therapy - exploits androgenic effects on muscle, bone, liver or brain in men. ${ }^{4}$ It can also be used to treat various functional $\mathrm{AD}$ states where an intact reproductive system responds adaptively to acute or chronic illness (eg, ageing, obesity, diabetes, cardiovascular disease, chronic infections or organ failure syndromes) by reducing testosterone secretion. These uses require highquality clinical evidence of efficacy, safety and cost-effectiveness from trials featuring randomisation and placebo controls; however, few such trials are available. ${ }^{5}$

Nevertheless, despite the absence of any new approved indications, there have been major and progressive increases in testosterone prescribing in Australia over the past two decades, with striking differences between states, increasing use of costlier newer products and partially effective regulatory curbs on unproven testosterone prescribing. ${ }^{6,7}$ Anecdotally, similar increases have been described in the United States, ${ }^{8,9}$ Switzerland $^{10}$ and the United Kingdom, ${ }^{11}$ but there has been no systematic study of multinational temporal trends in testosterone prescribing.

\begin{abstract}
Objective: To provide the first multinational survey of temporal trends in testosterone prescribing, given that anecdotal evidence indicates that it is increasing in some countries, including Australia.

Design: Sales data for all testosterone products were obtained for 41 countries for each year from 2000 to 2011. For each testosterone product type (injectable, implantable, oral, transdermal), units sold were converted into defined monthly doses per year, reflecting total testosterone prescribing per product.
\end{abstract}

Main outcome measures: National testosterone prescribing rate overall and per product type on a per capita basis.

Results: For every region and 37 of 41 countries, there was a major and progressive increase in defined monthly doses per year per capita over the 11 years surveyed. In most countries, the increases were steeper for the last half of the survey period. The proportion of testosterone prescribing represented by transdermal testosterone products, a surrogate measure of prescribing for older men, increased even more than did the total usage of testosterone products.

Conclusions: In the absence of any new indications, off-label testosterone prescribing has increased in most countries in 2000-2011, especially over the last half of the period. The increased testosterone prescribing appears to be primarily for older men and driven by clinical guidelines that endorse testosterone prescribing for age-related functional androgen deficiency (andropause). By eliminating the fundamental distinction between pathological and functional androgen deficiency, these guidelines tacitly promote increased testosterone prescribing, bypassing the requirement for high-quality clinical evidence of safety and efficacy and creating dramatic increases in prescription of testosterone products.

\section{Methods}

Data for sales of all testosterone products for each year from 2000 to 2011 inclusive were obtained from IMS Health for 41 countries. Countries were divided descriptively into six groups: the Anglosphere (Australia, Canada, Ireland, UK, US); Eastern Europe (Bulgaria, Croatia, Czechoslovakia, Estonia, Hungary, Latvia, Lithuania, Poland, Romania, Russia, Slovakia, Slovenia); Middle Europe (Austria, Belgium, France, Germany, Luxembourg, the Netherlands, Switzerland); Northern Europe (Denmark, Finland, Norway, Sweden); Southern Europe (Greece, Italy, Spain); and Asia (Hong Kong, China, Japan, Indonesia, Malaysia, the Philippines, Singapore, Thailand, Vietnam). Data were also obtained for Mexico.

Using the World Health Organization definition of standardised dosing (WHO Collaborating Centre for Drug Statistics Methodology, http:// www.whocc.no; described in detail elsewhere $^{6,7}$ ) the defined monthly dosage of testosterone was calculated for each product category, country and year. Testosterone products were grouped into four categories as injectable, implantable, oral or transdermal and, using a standard dosage regimen, sales of units were converted into monthly dose equivalents. For each country and region, total testosterone units were calculated for each product category per year. These total use estimates were adjusted to a population basis using annual national population estimates obtained from the US Census Bureau based on annual estimates for national population. This method uses commercial (wholesale) sales of testosterone products as a surrogate for testosterone prescribing and assumes (i) a constant proportion of adult males in each country's population over time and between countries, and (ii) a steady state existing between pur- 
Defined monthly doses (\% transdermal)*

\begin{tabular}{|c|c|c|c|c|c|c|c|c|c|c|c|c|}
\hline Country/region & 2000 & 2001 & 2002 & 2003 & 2004 & 2005 & 2006 & 2007 & 2008 & 2009 & 2010 & 2011 \\
\hline Australia & $\begin{array}{c}9.6 \\
(1 \%)\end{array}$ & $\begin{array}{c}11.5 \\
(10 \%)\end{array}$ & $\begin{array}{c}12.5 \\
(13 \%)\end{array}$ & $\begin{array}{c}12.2 \\
(13 \%)\end{array}$ & $\begin{array}{c}12.2 \\
(12 \%)\end{array}$ & $\begin{array}{c}13.1 \\
(13 \%)\end{array}$ & $\begin{array}{c}13.1 \\
(23 \%)\end{array}$ & $\begin{array}{c}13.6 \\
(23 \%)\end{array}$ & $\begin{array}{c}15.1 \\
(22 \%)\end{array}$ & $\begin{array}{c}16.5 \\
(22 \%)\end{array}$ & $\begin{array}{c}17.4 \\
(22 \%)\end{array}$ & $\begin{array}{c}17.9 \\
(23 \%)\end{array}$ \\
\hline Canada & $\begin{array}{c}10.0 \\
(0)\end{array}$ & $\begin{array}{c}11.3 \\
(3 \%)\end{array}$ & $\begin{array}{c}40.4 \\
(7 \%)\end{array}$ & $\begin{array}{c}82.1 \\
(86 \%)\end{array}$ & $\begin{array}{c}102.3 \\
(89 \%)\end{array}$ & $\begin{array}{c}108.5 \\
(90 \%)\end{array}$ & $\begin{array}{c}115.4 \\
(91 \%)\end{array}$ & $\begin{array}{c}122.3 \\
(91 \%)\end{array}$ & $\begin{array}{c}135.7 \\
(91 \%)\end{array}$ & $\begin{array}{l}220.0 \\
(95 \%)\end{array}$ & $\begin{array}{c}333.5 \\
(96 \%)\end{array}$ & $\begin{array}{l}385.5 \\
(97 \%)\end{array}$ \\
\hline Ireland & $\begin{array}{c}1.2 \\
(45 \%)\end{array}$ & $\begin{array}{c}1.9 \\
(41 \%)\end{array}$ & $\begin{array}{c}1.7 \\
(4 \%)\end{array}$ & $\begin{array}{c}1.6 \\
(54 \%)\end{array}$ & $\begin{array}{c}1.9 \\
(67 \%)\end{array}$ & $\begin{array}{c}2.3 \\
(72 \%)\end{array}$ & $\begin{array}{c}2.5 \\
(72 \%)\end{array}$ & $\begin{array}{c}2.9 \\
(74 \%)\end{array}$ & $\begin{array}{c}3.6 \\
(69 \%)\end{array}$ & $\begin{array}{c}4.6 \\
(64 \%)\end{array}$ & $\begin{array}{c}5.0 \\
(60 \%)\end{array}$ & $\begin{array}{c}5.4 \\
(58 \%)\end{array}$ \\
\hline United Kingdom & $\begin{array}{c}3.9 \\
(15 \%)\end{array}$ & $\begin{array}{c}4.1 \\
(16 \%)\end{array}$ & $\begin{array}{c}3.3 \\
(21 \%)\end{array}$ & $\begin{array}{c}3.6 \\
(24 \%)\end{array}$ & $\begin{array}{c}3.8 \\
(37 \%)\end{array}$ & $\begin{array}{c}4.2 \\
(43 \%)\end{array}$ & $\begin{array}{c}4.6 \\
(45 \%)\end{array}$ & $\begin{array}{c}5.4 \\
(49 \%)\end{array}$ & $\begin{array}{c}6.2 \\
(51 \%)\end{array}$ & $\begin{array}{c}7.9 \\
(47 \%)\end{array}$ & $\begin{array}{c}8.9 \\
(48 \%)\end{array}$ & $\begin{array}{c}9.8 \\
(50 \%)\end{array}$ \\
\hline United States & $\begin{array}{c}10.3 \\
(31 \%)\end{array}$ & $\begin{array}{c}15.3 \\
(53 \%)\end{array}$ & $\begin{array}{c}19.4 \\
(67 \%)\end{array}$ & $\begin{array}{c}19.0 \\
(61 \%)\end{array}$ & $\begin{array}{c}19.3 \\
(57 \%)\end{array}$ & $\begin{array}{c}24.2 \\
(66 \%)\end{array}$ & $\begin{array}{c}26.0 \\
(67 \%)\end{array}$ & $\begin{array}{c}32.6 \\
(71 \%)\end{array}$ & $\begin{array}{c}39.7 \\
(72 \%)\end{array}$ & $\begin{array}{c}46.5 \\
(69 \%)\end{array}$ & $\begin{array}{c}52.9 \\
(68 \%)\end{array}$ & $\begin{array}{c}98.5 \\
(78 \%)\end{array}$ \\
\hline Mexico & $\begin{array}{l}3.7 \\
(0)\end{array}$ & $\begin{array}{l}3.0 \\
(0)\end{array}$ & $\begin{array}{l}2.4 \\
(0)\end{array}$ & $\begin{array}{l}2.0 \\
(0)\end{array}$ & $\begin{array}{l}1.6 \\
(0)\end{array}$ & $\begin{array}{l}1.5 \\
(0)\end{array}$ & $\begin{array}{l}1.6 \\
(0)\end{array}$ & $\begin{array}{c}1.7 \\
(2 \%)\end{array}$ & $\begin{array}{c}1.9 \\
(6 \%)\end{array}$ & $\begin{array}{c}2.3 \\
(7 \%)\end{array}$ & $\begin{array}{c}2.0 \\
(8 \%)\end{array}$ & $\begin{array}{c}1.9 \\
(11 \%)\end{array}$ \\
\hline Eastern Europe $^{\dagger}$ & $\begin{array}{l}1.9 \\
(0)\end{array}$ & $\begin{array}{l}1.6 \\
(0)\end{array}$ & $\begin{array}{l}1.8 \\
(0)\end{array}$ & $\begin{array}{l}1.3 \\
(0)\end{array}$ & $\begin{array}{l}1.4 \\
(0)\end{array}$ & $\begin{array}{c}1.4 \\
(1 \%)\end{array}$ & $\begin{array}{c}1.7 \\
(4 \%)\end{array}$ & $\begin{array}{c}1.6 \\
(6 \%)\end{array}$ & $\begin{array}{c}1.8 \\
(7 \%)\end{array}$ & $\begin{array}{c}2.0 \\
(9 \%)\end{array}$ & $\begin{array}{c}1.8 \\
(9 \%)\end{array}$ & $\begin{array}{c}2.7 \\
(7 \%)\end{array}$ \\
\hline Middle Europe ${ }^{\ddagger}$ & $\begin{array}{c}4.3 \\
(7 \%)\end{array}$ & $\begin{array}{c}4.8 \\
(6 \%)\end{array}$ & $\begin{array}{c}5.1 \\
(6 \%)\end{array}$ & $\begin{array}{c}5.0 \\
(17 \%)\end{array}$ & $\begin{array}{c}4.3 \\
(27 \%)\end{array}$ & $\begin{array}{c}4.8 \\
(23 \%)\end{array}$ & $\begin{array}{c}5.5 \\
(24 \%)\end{array}$ & $\begin{array}{c}6.0 \\
(26 \%)\end{array}$ & $\begin{array}{c}6.5 \\
(27 \%)\end{array}$ & $\begin{array}{c}7.1 \\
(28 \%)\end{array}$ & $\begin{array}{c}7.8 \\
(29 \%)\end{array}$ & $\begin{array}{c}8.5 \\
(28 \%)\end{array}$ \\
\hline Northern Europe ${ }^{\varsigma}$ & $\begin{array}{c}4.5 \\
(14 \%)\end{array}$ & $\begin{array}{c}4.8 \\
(14 \%)\end{array}$ & $\begin{array}{c}5.1 \\
(14 \%)\end{array}$ & $\begin{array}{c}5.2 \\
(14 \%)\end{array}$ & $\begin{array}{c}5.5 \\
(26 \%)\end{array}$ & $\begin{array}{c}6.4 \\
(32 \%)\end{array}$ & $\begin{array}{c}10.5 \\
(47 \%)\end{array}$ & $\begin{array}{c}12.6 \\
(52 \%)\end{array}$ & $\begin{array}{c}14.8 \\
(56 \%)\end{array}$ & $\begin{array}{c}16.6 \\
(57 \%)\end{array}$ & $\begin{array}{c}19.3 \\
(60 \%)\end{array}$ & $\begin{array}{c}22.1 \\
(62 \%)\end{array}$ \\
\hline Denmark & $\begin{array}{c}1.6 \\
(7 \%)\end{array}$ & $\begin{array}{c}1.7 \\
(3 \%)\end{array}$ & $\begin{array}{l}1.7 \\
(0)\end{array}$ & $\begin{array}{l}1.8 \\
(0)\end{array}$ & $\begin{array}{c}2.0 \\
(7 \%)\end{array}$ & $\begin{array}{c}2.6 \\
(9 \%)\end{array}$ & $\begin{array}{c}4.9 \\
(9 \%)\end{array}$ & $\begin{array}{c}5.2 \\
(10 \%)\end{array}$ & $\begin{array}{c}5.4 \\
(13 \%)\end{array}$ & $\begin{array}{c}5.8 \\
(15 \%)\end{array}$ & $\begin{array}{c}6.3 \\
(20 \%)\end{array}$ & $\begin{array}{c}6.9 \\
(21 \%)\end{array}$ \\
\hline Finland & $\begin{array}{c}5.4 \\
(9 \%)\end{array}$ & $\begin{array}{c}5.5 \\
(7 \%)\end{array}$ & $\begin{array}{c}6.0 \\
(7 \%)\end{array}$ & $\begin{array}{c}6.3 \\
(10 \%)\end{array}$ & $\begin{array}{c}6.8 \\
(24 \%)\end{array}$ & $\begin{array}{c}7.9 \\
(28 \%)\end{array}$ & $\begin{array}{c}9.2 \\
(28 \%)\end{array}$ & $\begin{array}{c}10.1 \\
(29 \%)\end{array}$ & $\begin{array}{c}11.6 \\
(31 \%)\end{array}$ & $\begin{array}{c}13.5 \\
(31 \%)\end{array}$ & $\begin{array}{c}14.4 \\
(32 \%)\end{array}$ & $\begin{array}{c}15.1 \\
(34 \%)\end{array}$ \\
\hline Norway & $\begin{array}{c}5.1 \\
(10 \%)\end{array}$ & $\begin{array}{c}5.6 \\
(9 \%)\end{array}$ & $\begin{array}{c}6.1 \\
(10 \%)\end{array}$ & $\begin{array}{c}5.9 \\
(10 \%)\end{array}$ & $\begin{array}{c}6.7 \\
(20 \%)\end{array}$ & $\begin{array}{c}6.9 \\
(24 \%)\end{array}$ & $\begin{array}{c}8.3 \\
(2 \%)\end{array}$ & $\begin{array}{c}9.1 \\
(23 \%)\end{array}$ & $\begin{array}{c}9.5 \\
(23 \%)\end{array}$ & $\begin{array}{c}10.6 \\
(23 \%)\end{array}$ & $\begin{array}{c}11.5 \\
(24 \%)\end{array}$ & $\begin{array}{c}12.6 \\
(25 \%)\end{array}$ \\
\hline Sweden & $\begin{array}{c}5.5 \\
(20 \%)\end{array}$ & $\begin{array}{c}5.8 \\
(21 \%)\end{array}$ & $\begin{array}{c}6.0 \\
(22 \%)\end{array}$ & $\begin{array}{c}6.2 \\
(21 \%)\end{array}$ & $\begin{array}{c}6.3 \\
(34 \%)\end{array}$ & $\begin{array}{c}7.5 \\
(44 \%)\end{array}$ & $\begin{array}{c}15.8 \\
(67 \%)\end{array}$ & $\begin{array}{c}20.4 \\
(72 \%)\end{array}$ & $\begin{array}{c}25.0 \\
(75 \%)\end{array}$ & $\begin{array}{c}28.2 \\
(76 \%)\end{array}$ & $\begin{array}{c}34.1 \\
(77 \%)\end{array}$ & $\begin{array}{c}40.2 \\
(78 \%)\end{array}$ \\
\hline Southern Europe & $\begin{array}{c}5.6 \\
(2 \%)\end{array}$ & $\begin{array}{c}5.5 \\
(6 \%)\end{array}$ & $\begin{array}{c}5.3 \\
(6 \%)\end{array}$ & $\begin{array}{c}4.7 \\
(7 \%)\end{array}$ & $\begin{array}{c}4.5 \\
(11 \%)\end{array}$ & $\begin{array}{c}4.7 \\
(15 \%)\end{array}$ & $\begin{array}{c}5.1 \\
(15 \%)\end{array}$ & $\begin{array}{c}5.8 \\
(17 \%)\end{array}$ & $\begin{array}{c}6.3 \\
(19 \%)\end{array}$ & $\begin{array}{c}6.7 \\
(21 \%)\end{array}$ & $\begin{array}{c}6.9 \\
(21 \%)\end{array}$ & $\begin{array}{c}7.2 \\
(21 \%)\end{array}$ \\
\hline Asia** & $\begin{array}{l}0.4 \\
(0)\end{array}$ & $\begin{array}{l}0.4 \\
(0)\end{array}$ & $\begin{array}{l}0.4 \\
(0)\end{array}$ & $\begin{array}{l}0.3 \\
(0)\end{array}$ & $\begin{array}{l}0.3 \\
\text { (0) }\end{array}$ & $\begin{array}{l}0.3 \\
(0)\end{array}$ & $\begin{array}{l}0.3 \\
(0)\end{array}$ & $\begin{array}{l}0.3 \\
(0)\end{array}$ & $\begin{array}{l}0.4 \\
(0)\end{array}$ & $\begin{array}{l}0.4 \\
(0)\end{array}$ & $\begin{array}{l}0.4 \\
(0)\end{array}$ & $\begin{array}{l}0.5 \\
(0)\end{array}$ \\
\hline
\end{tabular}

* Per year per 1000 population; proportion given via transdermal products (gel, patch). † Bulgaria, Croatia, Czechoslovakia, Estonia, Hungary, Latvia, Lithuania, Poland, Romania, Russia, Slovakia, Slovenia. ¥Austria, Belgium, France, Germany, Luxembourg, the Netherlands, Switzerland. §̧ Denmark, Finland, Norway, Sweden. Я Greece, Italy, Spain. ** China (hospitals), Hong Kong, Indonesia, Japan, Malaysia, the Philippines, Singapore, Thailand, Vietnam.

chase, prescribing and clinical use of testosterone products according to their approved regimens.

\section{Results}

Over 11 years, total testosterone sales increased 12-fold globally, rising from $\$ 150$ million in 2000 to $\$ 1.8$ billion in 2011. For all regions and 37 of 41 countries, there was a progressive and increasingly steep increase in per capita use over that period (Box 1). This rise was markedly steeper from the middle of the decade, consistently in almost all countries (Box 2). In parallel, the proportion of testosterone sales as transdermal products also increased overall as well as in each region, especially in the second half of the decade for most countries (Box 1).

\section{Discussion}

This study shows a large and progressive increase in testosterone prescrib- ing across a wide range of countries over more than a decade. This is not due to any new indications for testosterone, and the rising trend accelerated over the last half decade of the survey period. The most dramatic increases in per capita testosterone prescribing were observed in Canada, which displayed an almost fourfold higher rate than the next country, its southern neighbour the US (however, a similar pattern did not occur between the US and its southern neighbour Mexico). This increase is most probably due to internet pharmacies physically based in Canada, which appear not to be subject to national prohibitions of import and export controls of androgens as restricted drugs and are beyond the US Food and Drug Administration's regulatory reach. In contrast, other national data are likely to reflect use only within a country. These findings closely resemble, and widen, the spectrum of prescription drug misuse, which has been described as a mod- ern epidemic ${ }^{12}$ involving the misuse of psychoactive drugs such as opioids, sedatives and stimulants, as well as non-psychoactive drugs such as antibiotics. ${ }^{13,14}$ Notably, testosterone has long been known to have mood-elevating effects, ${ }^{15}$ reflected in its modest efficacy as an adjuvant antidepressant, ${ }^{16,17}$ and hypomania as an overdosage side effect. ${ }^{18}$

Testosterone prescribing was already increasing before 2000 when this survey commenced. ${ }^{6,8}$ The reasons for this coordinated global increase in testosterone prescribing are speculative. The dramatic differences between even neighbouring countries is an indication that differences in local or regional marketing are responsible as shown previously for Australian states. ${ }^{6,8}$ The impact of direct-to-consumer advertising in the US, materially unchanged during the period of survey, would be largely confined to North America. More likely, a major contributor, especially in the second half of the decade, 
2 Increasing testosterone use, 2000-2011, in selected countries

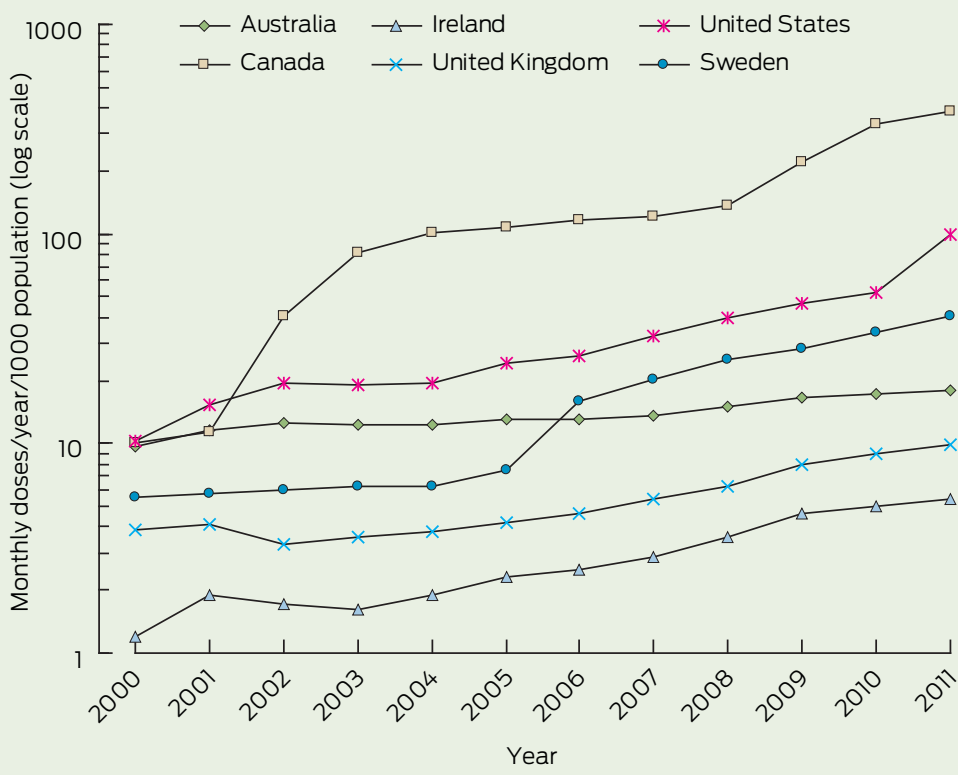

appears to be the permissive US ${ }^{19}$ and European-based ${ }^{20}$ guidelines for testosterone prescribing, first published in 2005-2006 and republished virtually unchanged 4 years later. ${ }^{21,22}$ The European-based guidelines appeared in seven different peer-reviewed journals, and both guidelines have been frequently cited (> 1300 times; Thomson Reuters Web of Knowledge, 20 June 2013, http://wok.mimas.ac.uk/ news/2013/20130620.html). These guidelines are widely understood to define and endorse testosterone prescription for age-related functional $\mathrm{AD}$ (also known as andropause or late-onset hypogonadism). ${ }^{23}$ In eliminating the distinction between pathological and functional AD, these guidelines promote unproven offlabel testosterone prescribing, particularly for older men, bypassing the need for high-quality evidence from randomised placebo-controlled clinical trials. ${ }^{5}$

The rising proportion of transdermal products may reflect that the increased testosterone prescribing was primarily for older men, although the age and indications for treatment were not available for this analysis. Daily-use testosterone products are a convenient surrogate metric for testosterone prescribing for older men, as short-acting products allow for rapid cessation with a new diagnosis of prostate cancer. In contrast, younger men, facing a lifetime of treatment, prefer long-acting injections, which facilitate the continuity and convenience of long-term treatment. ${ }^{24}$

The known prevalence of pathological AD (about $0.5 \%$ of $\mathrm{men}^{24}$ ) equates to about 15 defined monthly doses per year per 1000 population. Population-linkage registry data from the $\mathrm{UK}^{25}$ and Denmark ${ }^{26}$ indicate severe underdiagnosis of Klinefelter syndrome (KS), the most frequent cause of pathological AD. Nevertheless, it is highly unlikely that recent steep increases in testosterone prescribing can be attributed to rectifying underdiagnosis of KS. Not only does total testosterone prescribing in some countries exceed the maximum amount that could be attributed to pathological $\mathrm{AD}$, there is no evidence that the diagnosis of KS has increased in recent years. ${ }^{6,27}$ In contrast, the estimated population prevalence of age-related functional AD among older men is up to $40 \%,{ }^{28}$ more usually $10 \%-25 \%$, ${ }^{29-31}$ with even the lowest estimates of $2 \%-3 \%{ }^{32}$ representing major (five- to 100-fold) increases in potential market size over pathological AD.

The potential harm of testosterone overuse in older men is highlighted by adverse cardiovascular effects of testosterone in frail, older men. ${ }^{33}$ Nevertheless, previous longer and higher dose studies produced no similar excess cardiovascular harms, 34 although the bias in underreporting of cardiovascular harm in industrysponsored studies may lead to underestimating the risk. ${ }^{35}$ Such testosterone-induced cardiovascular harm predicts that the substantial increases in testosterone prescribing for older men may lead to increased incidence of cardiovascular disease among older men, warranting ongoing populationlevel surveillance. In the interim, testosterone prescribing for functional $\mathrm{AD}$, notably among older men without pathological hypogonadism, should be confined to well controlled and adequately powered clinical trials that aim to determine the efficacy and safety of testosterone prescribing for andropause.

Limitations of this study include that no information on patient age or the indications for prescribing was available. However, it is most likely that the increased prescribing was for older men with functional AD. The study also did not include testosterone sold by compounding pharmacies. Androgens (including testosterone) obtained illicitly via the internet or other non-medical sources are at least partly included, to the extent that virtually all testosterone originates from commercial production facilities that supply wholesalers.

This study provides the first multinational view of testosterone prescribing. It shows coordinated, global increases in off-label testosterone prescribing, apparently mainly for older men, driven by permissive guidelines promoting evidence-free prescribing for functional AD including andropause. This overuse of testosterone shares many features of, and expands the spectrum of, prescription drug misuse.

Acknowledgements: I thank Lam Ly for his help with data management and Nicole Sweetman of IMS Health for providing the data.

Competing interests: No relevant disclosures.

Received 23 Jan 2013, accepted 4 Aug 2013.

1 Hamilton JB. Treatment of sexual underdevelopment with synthetic male hormone substance. Endocrinology 1937; 21: 649-654.

2 David K, Dingmanse E, Freud J, Lacqueur E. [Uber krystallinisches mannliches Hormon aus Hoden (Testosteron), wirksamer als aus Harn oder aus Cholestrin bereites Androsteron] [German]. Zeischrift Physiologische Chemie 1935; 233: 281-282.

3 Ruzicka L, Wettstein A. [Uber die krystallische Herstellung des Testikelhormons, Testosteron (androsten-3-on-17-ol)] [German]. Helv Chim Acta 1935; 18: 1264-1275. 
4 Handelsman DJ. Androgen therapy in nongonadal disease. In: Nieschlag E, Behre HM, editors. Testosterone: action, deficiency, substitution. 4th ed. Cambridge: Cambridge University Press, 2012: 372-407.

5 Liverman CT, Blazer DG, editors. Testosterone and aging: clinical research directions. Washington, DC: The National Academies Press, 2004.

6 Handelsman DJ. Trends and regional differences in testosterone prescribing in Australia, 19912001. Med J Aust 2004; 181: 419-422.

7 Handelsman DJ. Pharmacoepidemiology of testosterone prescribing in Australia, 1992-2010. Med J Aust 2012; 196: 642-645.

8 Bhasin S, Singh AB, Mac RP, et al. Managing the risks of prostate disease during testosterone replacement therapy in older men: recommendations for a standardized monitoring plan. J Androl 2003; 24: 299-311.

9 Baillargeon J, Urban RJ, Ottenbacher KJ, et al. Trends in androgen prescribing in the United States, 2001 to 2011. JAMA Intern Med 2013; Jun 3 [Epub ahead of print]. doi: 10.1001/ jamainternmed.2013.6895.

10 Nigro N, Christ-Crain M. Testosterone treatment in the aging male: myth or reality? Swiss Med Wkly 2012; 142: w13539.

11 Gan EH, Pattman S, Pearce S, Ouinton R. A UK epidemic of testosterone prescribing, 2001-2010. Clin Endocrinol (Oxf) 2013; Mar 10 [Epub ahead of print]. doi: 10.1111/cen.12178.

12 Hernandez SH, Nelson LS. Prescription drug abuse: insight into the epidemic. Clin Pharmacol Ther 2010; 88: 307-317.

13 Ranji SR, Steinman MA, Shojania KG, Gonzales R. Interventions to reduce unnecessary antibiotic prescribing: a systematic review and quantitative analysis. Med Care 2008; 46: 847-862.

14 Andrews T, Thompson M, Buckley DI, et al. nterventions to influence consulting and antibiotic use for acute respiratory tract infections in children: a systematic review and meta-analysis. PLOS One 2012; 7: e30334.
15 Altschule MD, Tillotson KJ. The use of testosterone in the treatment of depressions. $N$ Engl J Med 1948; 239: 1036-1038.

16 Shores MM, Kivlahan DR, Sadak TI, et al. A randomized, double-blind, placebo-controlled study of testosterone treatment in hypogonadal older men with subthreshold depression (dysthymia or minor depression). JClin Psychiatry 2009; 70:1009-1016.

17 Pope HG Jr, Amiaz R, Brennan BP, et al. Parallelgroup placebo-controlled trial of testosterone gel in men with major depressive disorder displaying an incomplete response to standard antidepressant treatment $J$ Clin Psychopharmacol 2010; 30: 126-134.

18 Kanayama G, Hudson J, Pope HG Jr. Illicit anabolic-androgenic steroid use. Horm Behav 2010; 58: 111-121.

19 Bhasin S, Cunningham GR, Hayes FJ, et al. Testosterone therapy in adult men with androgen deficiency syndromes: an endocrine society clinical practice guideline. J Clin Endocrinol Metab 2006; 91: 1995-2010.

20 Nieschlag E, Swerdloff R, Behre HM, et al. Investigation, treatment and monitoring of lateonset hypogonadism in males: ISA, ISSAM, and EAU recommendations. Int J Androl 2005; 28 : $125-127$.

21 Bhasin S, Cunningham GR, Hayes FJ, et al. Testosterone therapy in men with androgen deficiency syndromes: an Endocrine Society clinical practice guideline. J Clin Endocrinol Metab 2010; 95: 2536-2559.

22 Wang C, Nieschlag E, Swerdloff R, et al. Investigation, treatment, and monitoring of lateonset hypogonadism in males: ISA, ISSAM, EAU,

EAA, and ASA recommendations. J Androl 2009; 30: $1-9$

23 Braun SR. Promoting "low T": a medical writer's perspective. JAMA Intern Med 2013; Jun 3 [Epub ahead of print]. doi:10.1001/ jamainternmed.2013.6892.

24 Handelsman DJ. Androgen physiology, pharmacology and abuse. In: DeGroot $\sqcup$, Jameson JL, editors. Endocrinology. 6th ed.
Philadelphia: Elsevier Saunders, 2010: 24692498.

25 Swerdlow AJ, Higgins CD, Schoemaker MJ, et al. Mortality in patients with Klinefelter syndrome in Britain: a cohort study. J Clin Endocrinol Metab 2005; 90:6516-6522.

26 Bojesen A, Juul S, Gravholt CH. Prenatal and postnatal prevalence of Klinefelter syndrome: a national registry study. J Clin Endocrinol Metab 2003: 88: 622-626.

27 Herlihy AS, Halliday JL, Cock ML, McLachlan RI. The prevalence and diagnosis rates of Klinefelter syndrome: an Australian comparison. Med J Aust 2011; 194: 24-28.

28 Mulligan T, Frick MF, Zuraw OC, et al. Prevalence of hypogonadism in males aged at least 45 years: the HIM study. Int J Clin Pract 2006; 60: 762-769.

29 Araujo AB, O'Donnell AB, Brambilla DJ, et al. Prevalence and incidence of androgen deficiency in middle-aged and older men: estimates from the Massachusetts Male Aging Study. J Clin Endocrinol Metab 2004; 89: 5920-5926.

30 Orwoll E, Lambert LC, Marshall LM, et al. Testosterone and estradiol among older men. JClin Endocrinol Metab 2006; 91: 1336-1344.

31 Haring R, Ittermann T, Völzke H, et al. Prevalence, incidence and risk factors of testosterone deficiency in a population-based cohort of men: results from the study of health in Pomerania. Aging Male 2010; 13: 247-257.

32 Wu FC, Tajar A, Beynon JM, et al. Identification of late-onset hypogonadism in middle-aged and elderly men. N Engl J Med 2010; 363: 123-135.

33 Basaria S, Coviello AD, Travison TG, et al. Adverse events associated with testosterone administration. NEngl J Med 2010; 363: 109-122.

34 Handelsman DJ. An old emperor finds new clothing: rejuvenation in our time. Asian J Androl 2011; 13:125-129.

35 Xu L, Freeman G, Cowling BJ, Schooling CM. Testosterone therapy and cardiovascular events among men: a systematic review and metaanalysis of placebo-controlled randomized trials. BMC Med 2013; 11: 108.

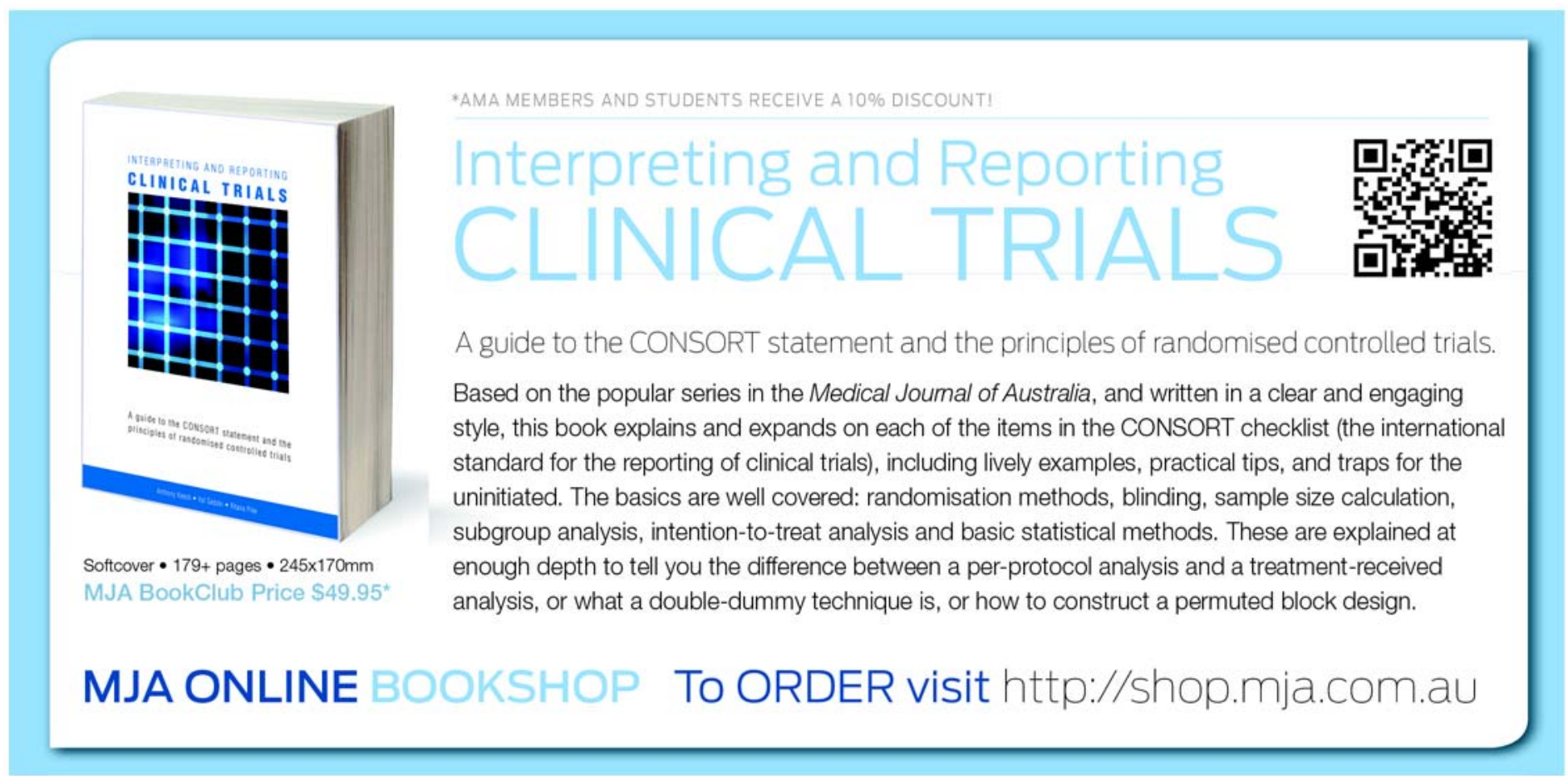

